\title{
TEKNIK RESTRUKTURISASI KOGNITIF DAN PROBLEM BASED COPING UNTUK MENURUNKAN STRES AKADEMIK SISWA: STUDI KOMPARATIF
}

\author{
Aminullah, M. Ramli, Nur Hidayah \\ Universitas Negeri Malang, Jalan Semarang 5 Malang 65145 \\ Email: aminullahzaky@yahoo.co.id
}

\begin{abstract}
In adolescence, adolescent to by dozens feel confronted many by change and demand quickly causing they experience of academic stress. Handling technique to overcome and reducing academic stress which selected is restructuring cognitive technique and problem based coping. Target of this research is to know do there is difference of restructuring cognitive technique and problem based coping to reduce academic stress student. Statistical analysis the used is wilcoxon signed ranks test advised of that restructuring cognitive technique and problem based coping both of the same effective to reduce academic stress student. But after analysed to use mann-whitney u-test obtained by result of that there is difference of restructuring cognitive technique and problem based coping in reduce academic stress student.
\end{abstract}

Keywords: restructuring cognitive technique; problem based coping; students academic stress

\begin{abstract}
Abstrak: Di masa remaja, tidak sedikit remaja merasa banyak dihadapkan oleh tuntutan dan perubahan cepat yang menyebabkan mereka mengalami stres akademik. Teknik penanganan untuk mengatasi dan mereduksi stres akademik yang dipilih adalah teknik restrukturisasi kognitif dan problem based coping. Tujuan penelitian ini adalah untuk mengetahui apakah ada perbedaan teknik restrukturisasi kognitif dan problem based coping untuk menurunkan stres akademik siswa. Analisis statistik nonparametrik yang digunakan adalah wilcoxon signed ranks test menunjukkan bahwa teknik restrukturisasi kognitif dan problem based coping sama-sama efektif untuk menurunkan stres akademik siswa. Namun setelah dianalisis menggunakan mannwhitney u-test diperoleh hasil bahwa ada perbedaan teknik restrukturisasi kognitif dan problem based coping dalam menurunkan stres akademik siswa.
\end{abstract}

Kata kunci: teknik restrukturisasi kognitif; problem based coping; stres akademik siswa

Manusia adalah makhluk yang senantiasa mengalami perkembangan. Perkembangan tersebut terjadi melalui fase kehidupan tertentu. Salah satu fase perkembangan manusia adalah masa remaja. Masa remaja merupakan masa transisi perkembangan antara masa kanak-kanak dan dewasa yang umumnya dimulai pada usia 10 atau 11 tahun dan berakhir pada usia akhir belasan tahun atau awal dua puluhan tahun (Papalia, et al., 2001; Sultoni, et al., 2018). Pada masa ini, remaja mengalami perkembangan di semua aspek baik fisik, kognitif, serta psikososial. Dalam proses perkembangannya remaja mengalami banyak tantangan yang datang dari lingkungan di luar dirinya. Remaja dihadapkan pada beberapa tekanan, misalnya dalam hubungan pertemanannya dengan lawan jenis, hubungan dengan keluarga, prestasi akademis, dalam menghadapi tugas sekolah, konflik dengan guru, serta manajemen diri (Yahav \& Cohen, 2008; Hidayah, et al., 2017).

Pada jenjang sekolah menengah (SMP/MTs), remaja berada pada fase perkembangan remaja awal. Fase ini sering digambarkan sebagai masa yang paling indah dan tidak terlupakan. Hal ini dikarenakan pada fase ini merupakan masa yang penuh dengan kegembiraan dan tantangan. Salah satu tantangan yang dihadapi remaja adalah kondisi identik yang disebut dengan kata pemberontakan, karena banyaknya goncangan dan perubahan yang cukup tidak sehat dari masa sebelumnya. Hal ini 
sesuai dengan pendapat Payne yang menyatakan masa remaja merupakan masa storm and stress, dimana merupakan masa yang bergolak dan berisi konflik serta perubahan suasana hati yang dapat menyebabkan depresi (Taufik \& Ifdil, 2013; Gunawan, et al., 2014). Kondisi ini disebabkan karena banyaknya goncangan-goncangan dan perubahan yang cukup radikal dari masa sebelumnya.

Perubahan tuntutan belajar dari masa sebelumnya juga menyebabkan munculnya gejala stres. Kondisi ini antara lain disebabkan oleh tuntutan yang tinggi terhadap prestasi siswa (Taufik \& Ifdil, 2013). Hal ini juga sejalan dengan pendapat Baldwin yang menyatakan menghadapi beban pelajaran yang dirasa cukup berat di sekolah akan dapat menimbulkan stres pada remaja, terutama bagi remaja high school, mengingat pada masa ini remaja pada umumnya mengalami tekanan dari pihak sekolah dan kadangkala orangtua untuk memperoleh nilai yang tinggi agar dapat melanjutkan pendidikan ke perguruan tinggi favorit (Desmita, 2010; Suraya, et al., 2012). Rainham menegaskan bahwa pada masamasa sekolah menengah di satu sisi merupakan kesempatan untuk mendapat pengalaman yang sangat berharga bagi remaja, tetapi pada sisi lain mereka dihadapkan dengan banyaknya tuntutan dan perubahan cepat yang membuat mereka mengalami masa-masa yang penuh dengan stres (Desmita, 2010).

Lingkungan sekolah seharusnya menjadi tempat yang nyaman dan sehat untuk perkembangan fisik dan psikis siswa. Akan tetapi bagi sebagian siswa, sekolah dengan segala elemennya justru menjadi sesuatu yang menakutkan. Elemenelemen yang dimaksud antara lain kurikulum yang dirasa terlalu berat, cara mengajar atau perlakuan guru yang menekan atau merendahkan, serta lingkungan pergaulan sebaya yang tidak sehat. Fakta menunjukkan banyak siswa di sekolah lanjutan mengalami tekanan-tekanan yang sangat serius. Tekanan itu bersumber dari faktor akademik berupa cara mengajar dan bahan pelajaran yang diajarkan serta tekanan sosial, berupa pengaruh dari teman sebaya. Penelitian terhadap siswasiswa pada salah satu sekolah unggulan di Jakarta menemukan adanya fenomena stres yang dialami siswa di sekolah. Sekitar $40,74 \%$ siswa merasa terbebani dengan keharusan mempertahankan peringkat sekolah; 62,96\% siswa merasa cemas menghadapi ujian semester; $82,72 \%$ siswa merasa takut mendapat nilai ulangan yang jelek; $80,25 \%$ merasa bingung menyelesaikan pekerjaan rumah yang terlalu banyak; dan 50,62\% siswa merasa letih mengikuti perpanjangan waktu belajar di sekolah (Gusniati, 2002).

Stres adalah suatu kondisi yang disebabkan adanya ketidaksesuaian antara situasi yang diinginkan dengan keadaan biologis, psikologis atau sistem sosial individu tersebut (Sarafino, 2006). Maksudnya apabila dikaitkan dengan siswa adalah ketidaksesuaian yang dihadapi oleh siswa berada pada tuntutan lingkungan dengan sumber daya aktual yang dimiliki siswa. Stres pada setiap siswa biasanya juga terjadi karena banyaknya harapan dan tuntutan dalam bidang akademik yang sering disebut dengan stres akademik. Stres akademik merupakan salah satu masalah belajar yang sudah banyak ditemui di sekolah. Terkait dengan pentingnya upaya bantuan bagi siswa yang mengalami stres akademik, konselor perlu merancang layanan bimbingan konseling yang tepat. Siswa yang mengalami stres akademik memerlukan upaya bantuan bimbingan akademik yang bersifat responsif. Layanan responsif merupakan pemberian bantuan kepada siswa yang menghadapi kebutuhan dan masalah yang memerlukan pertolongan dengan segera, sebab jika tidak segera dibantu dapat menimbulkan gangguan dalam proses pencapaian tugas-tugas perkembangan (ABKIN, 2007).

Sebagai bagian integral dalam pendidikan, bimbingan dan konseling memegang peranan penting dalam membantu siswa mengatasi berbagai permasalahan akademik yang dapat menghambat perkembangan belajar siswa. Dengan kata lain, layanan responsif yang tepat bagi permasalahan stres akademik siswa melalui kegiatan bimbingan yang diorientasikan, agar siswa dapat mengelola stimulus yang datang, merespon dengan pikiran dan perilaku yang positif. Salah satu teknik yang dianggap efektif untuk mengatasi stres akademik adalah teknik restrukturisasi kognitif. Restukturisasi kognitif adalah salah satu teknik dalam pendekatan kognitif behavioral yang berfokus pada aspek kognitif individu. Teknik restrukturisasi kognitif baik digunakan untuk 
konseli yang mengalami distress, distorsi kognitif, dan untuk konseli yang memperlihatkan resistensi terhadap metode perubahan perilaku (Dobson \& Dobson, 2009).

Stres akademik merupakan salah satu bentuk distress yang diakibatkan oleh pikiran negatif siswa terhadap tuntutan-tuntutan akademik di sekolah. Kegiatan bimbingan berorientasi pada perubahan kognitif yang menyimpang akibat ketidaksiapan siswa dalam menghadapi tuntutan yang datang yang dipersepsi merugikan atau mengancam diri. Postulat dari restukturisasi kognitif adalah perasaan negatif bersumber dari kekeliruan individu dalam menginterpretasi lingkungan. Perasaan dan perilaku individu ditentukan oleh cara individu mengkonstruksi lingkungannya. Selain itu, stress dapat muncul apabila ada tuntutan-tuntutan pada diri seseorang yang dirasa menantang, membebani atau melebihi sumber daya yang dimiliki seseorang (Sarafino, 2006). Keadaan ini tidak dapat dibiarkan berlarut-larut. Oleh karena itu, harus dilakukan sesuatu untuk mengatasi stres yang muncul. Usaha mengatasi stres ini dikenal dengan istilah coping.

Coping juga merupakan usaha yang dilakukan individu untuk mengatasi tuntutan-tuntutan yang menekan atau menimbulkan perubahan emosi. Ada dua jenis coping, yaitu: problem-focused coping dan emotion-focused coping (Lazarus \& Folkman, 1984). Dalam problem-focused coping, individu mengurangi ketegangan dengan cara melakukan sesuatu, seperti memodifikasi, atau meminimalisir situasi yang sedang dihadapi. Sedangkan pada emotion-focused coping, individu mengurangi ketidaknyamanan tersebut dengan menggunakan pertahanan, seperti penilaian positif, penyangkalan, dan berpikir dengan penuh pengharapan. Strategi coping ini dapat dibagi menjadi delapan subkategori. Dua diantaranya, yaitu: confrontive coping dan planful problem-solving yang merupakan bagian dari problem-focused coping. Sedangkan lima lainnya, yaitu: distancing, selfcontrol, accepting responsibility, escape-avoidance, dan positive reappraisal yang merupakan bagian dari emotion-focused coping. Satu kategori sisanya, yaitu seeking social support yang merupakan bagian dari problem-focused coping dan emotion-focused coping (Lazarus \& Folkman; 1984).

Dari paparan teori untuk mereduksi stres akademik siswa, peneliti ingin mengkaji perbedaan teknik restrukturisasi kognitif dan problem based coping untuk menurunkan stres akademik siswa melalui konseling kelompok. Konseling kolompok disini selain untuk mereduksi stres akademik siswa, diharapkan juga membantu siswa dalam mengembangkan pemahaman dan keterampilan dalam belajar dan memecahkan masalah-masalah belajar atau akademik. Sehingga nantinya penelitian ini diharapkan dapat memperkaya repertoire (daftar-daftar) teknik intervensi konselor dalam membantu siswa yang mengalami masalah stres akademik, dan berguna untuk memperkuat dasar pijakan teori bagi peneliti lain yang akan melakukan penelitian lebih lanjut dalam topik terkait, serta memperkuat bukti empiris mengenai keefektifan teknik restrukturisasi kognitif dan problem based coping dalam mengentaskan berbagai permasalahan, khususnya masalah stres akademik.

\section{METODE}

Penelitian ini menggunakan pendekatan kuantitatif dengan pretest and posttest with control group design (Hadi, et al., 2018; Gunawan, 2016). Subjek penelitian dipilih menggunakan teknik purposive sampling, subjek yang teridentifikasi mempunyai gejala stres akademik yang tinggi dan hampir tinggi (sedang). Pengidentifikasian dilakukan dengan menyebarkan angket skala stres akademik kepada seluruh siswa kelas VII MTsN Wonorejo, dan diperoleh 10 orang siswa sebagai kelompok eksperimen yang diberi perlakuan menggunakan teknik restrukturisasi kognitif dan 10 orang siswa sebagai kelompok kontrol yang diberi perlakuan menggunakan problem based coping.

Bahan perlakuan sebelumnya divalidasi oleh 2 orang ahli, dan diperoleh hasil validasi ratarata dinyatakan bahwa bahan perlakuan layak digunakan. Untuk angket skala stres akademik yang dikembangkan oleh peneliti diuji validitasnya dan diperoleh 38 item dinyatakan valid dari 66 item yang diujikan. Uji reliabilitas menggunakan model analisis reliabilitas Split-Half diperoleh hasil nilai $r_{\text {hitung }}=0,926$, sehingga dapat disimpulkan bahwa item-item dinyatakan reliabel, atau dengan kata lain dapat digunakan sebagai alat ukur stres akademik siswa.

Untuk mengetahui keefektifan teknik restrukturisasi kognitif dan problem based coping untuk menurunkan stres akademik siswa digunakan 
dua teknik analisis statistik nonparametrik, yakni: The Wilcoxon Matched-Pairs Signed-ranks Test dan The Mann-Withney U Test (Gunawan, 2013). Teknik Wilcoxon diaplikasikan untuk mengetahui keefektifan teknik restrukturisasi kognitif dan problem based coping untuk menurunkan stres akademik siswa, sedangkan teknik MannWithney U Test digunakan untuk membandingkan apakah ada perbedaan antara penggunaan teknik restrukturisasi kognitif dan problem based coping untuk menurunkan stres akademik siswa. Selanjutnya untuk keperluan analisis data tersebut digunakan program SPSS 16.0 for Windows.
HASIL

\section{Hasil Pretest dan Posttest Kelompok Eksperimen dan Kelompok Kontrol}

Pretest dalam penelitian ini bertujuan untuk mengukur tingkat stres akademik siswa berkaitan dengan perlakuan yang diberikan, sehingga pemberian perlakuan dapat memperbaiki atau menurunkan stres akademik siswa. Data pretest stres akademik siswa disajikan dalam bentuk nilai rata-rata seperti terlihat pada Gambar 1.

Berdasarkan Gambar 1 dapat diketahui bahwa nilai rata-rata stres akademik siswa kelompok

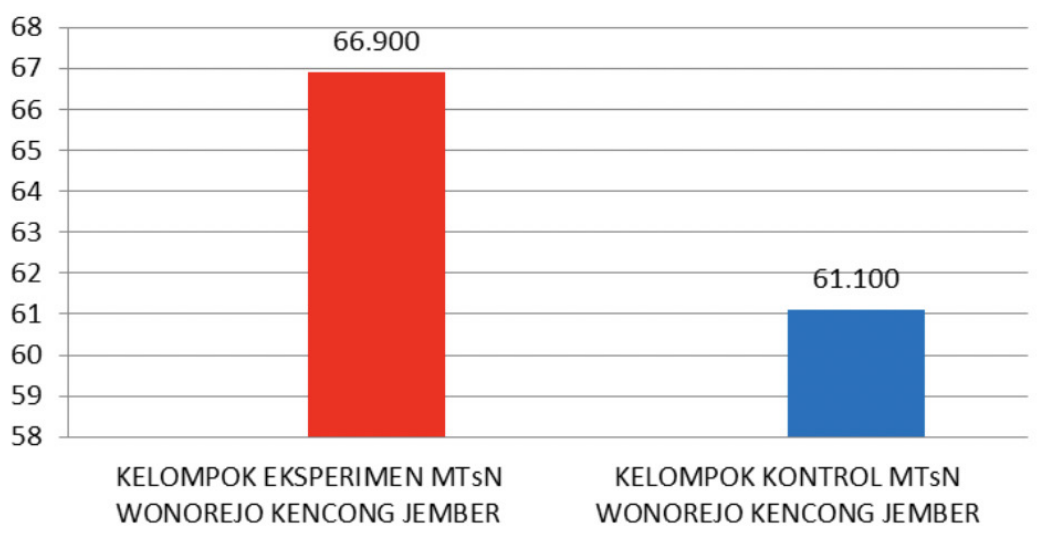

Gambar 1 Nilai Rata-rata Pretest Stres Akademik Kelompok Siswa

eksperimen lebih tinggi dibanding dengan nilai rata-rata stres akademik siswa kelompok kontrol. Sedangkan Posttest dalam penelitian ini berfungsi untuk mengukur sejauh mana efektivitas dari suatu pemberian perlakuan terhadap penurunan stres akademik siswa. Posttest diberikan kepada siswa kelompok eksperimen setelah diberikan perlakuan menggunakan teknik restrukturisasi kognitif dan kelompok kontrol menggunakan problem based coping. Data posttest disajikan dalam bentuk nilai rata-rata seperti pada Gambar 2.

Berdasarkan Gambar 2 dapat diketahui bahwa nilai rata-rata kelompok siswa yang diberikan perlakuan menggunakan teknik restrukturisasi kognitif lebih rendah dibanding dengan kelompok siswa yang diberikan perlakuan menggunakan problem based coping.

\section{Uji Asumsi Data}

Teknik statistik yang digunakan dalam penelitian iniadalah teknik statistiknonparametrik, sehingga data setiap variabel tidak dipersyaratkan berbentuk distribusi normal. Untuk mengetahui normalitas distribusi data, dilakukan analisis uji normalitas distribusi menggunakan analisis Kolmogorov Smirnova ${ }^{\mathrm{a}}$. Hasil analisis dapat dilihat pada Tabel 1.

Hasil analisis normalitas distribusi data pretest kelompok siswa Kolmogorov-Smirnov ${ }^{\mathrm{a}}$ pada Tabel 1 menunjukkan nilai statistik 0,293 dengan degree of freedom (df) 10, dan sig 0,015. Artinya normalitas distribusi data pretest tidak berdistribusi normal, sedangkan normalitas distribusi data postest kelompok siswa setelah diberikan perlakuan dengan teknik restrukturisasi kognitif menunjukkan nilai statistik 0,300 dengan degree of freedom (df) 10, dan sig 0,011. Artinya normalitas distribusi data postest tidak berdistribusi normal. Dengan demikian teknik statistik nonparametrik dapat dilanjutkan (ke uji hipotesis). Untuk normalitas distribusi data kelompok siswa yang diberikan perlakuan menggunakan problem based coping, dapat dilihat pada Tabel 2. 


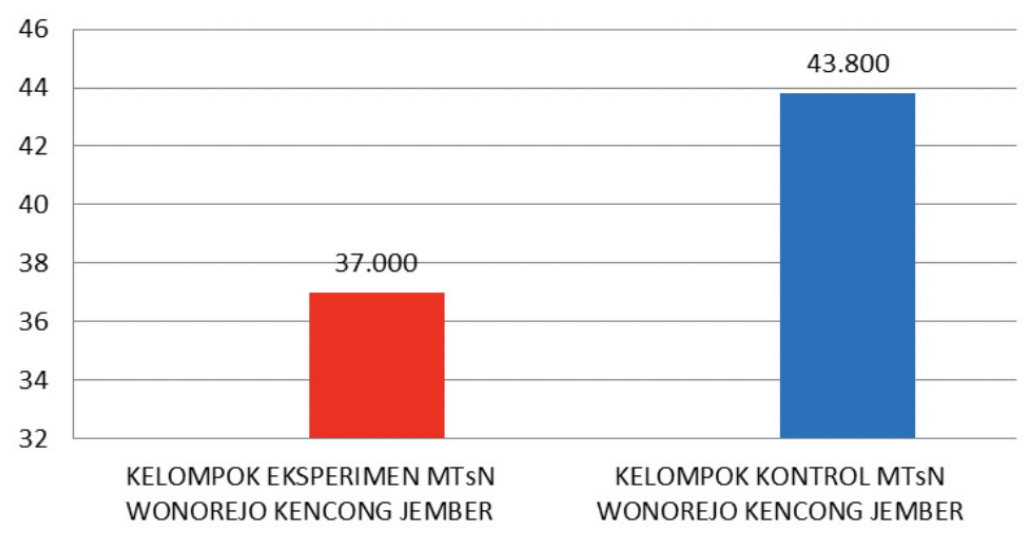

Gambar 2 Nilai Rata-rata Posttest Stres Akademik Kelompok Siswa

Tabel 1 Tests of Normality Kelas Teknik Restrukturisasi Kognitif

\begin{tabular}{lcccccc}
\hline & \multicolumn{3}{c}{ Kolmogorov-Smirnov } & \multicolumn{3}{c}{ Shapiro-Wilk } \\
\cline { 2 - 7 } & Statistic & Df & Sig. $^{\text {a }}$ & Statistic & Df & Sig. \\
\hline Pretest & .293 & 10 & .015 & .855 & 10 & .066 \\
Postest & .300 & 10 & .011 & .803 & 10 & .016 \\
\hline
\end{tabular}

a. Lilliefors Significance Correction

Tabel 2 Tests of Normality Kelas Problem Based Coping

\begin{tabular}{lcccccc}
\hline & \multicolumn{2}{c}{ Kolmogorov-Smirnov } & \multicolumn{3}{c}{ Shapiro-Wilk } \\
\cline { 2 - 7 } & Statistic & df & Sig. & Statistic & Df & Sig. \\
\hline Pretest & .297 & 10 & .012 & .745 & 10 & .003 \\
Posttest & .333 & 10 & .002 & .639 & 10 & .000 \\
\hline
\end{tabular}

a. Lilliefors Significance Correction

Hasil analisis Kolmogorov-Smirnov ${ }^{\mathrm{a}}$ pada Tabel 2 diperoleh normalitas distribusi data pretest kelompok siswa dengan nilai statistik 0,297, degree of freedom (df) 10, dan $\operatorname{sig} 0,012$. Artinya data pretest tidak berdistribusi normal, sedangkan distribusi data postest kelompok siswa setelah diberikan perlakuan dengan teknik problem based coping menunjukkan nilai statistik 0,033 dengan degree of freedom (df) 10 , dan sig 0,002 . Artinya data postest tidak berdistribusi normal, sehingga teknik statistik dapat dilanjutkan (ke uji hipotesis).

\section{Uji Hipotesis}

Hasil analisis normalitas distribusi data pretest dan posttest kelompok siswa yang diberi perlakuan menggunakan teknik restrukturisasi kognitif dan problem based coping sama-sama tidak membentuk distribusi normal, maka teknik statistik nonparametrik dapat dilanjutkan. Teknik statistik nonparametrik yang dilakukan dengan hasil sebagai berikut.

\section{Wilcoxon Matched-pairs Signed-ranks Test}

Analisis Wilcoxon digunakan untuk mengetahui keefektifan teknik restrukturisasi kognitif dan problem based coping dalam menurunkan stres akademik siswa. Hasil uji analisis wilcoxon dapat dilihat dari hasil berikut.

\section{Keefektifan Teknik Restrukturisasi Kognitif untuk Menurunkan Stres Akademik Siswa}

Keefektifan teknik restrukturisasi kognitif untuk menurunkan stres akademik siswa dapat dilihat dalam Tabel 3.

Tabel 3 Descriptive Statistics Kelompok Eksperimen

\begin{tabular}{llcccc}
\hline & N & Mean & Std. Deviation & Minimum & Maximum \\
\hline Pretest & 10 & 66.900 & 3.84274 & 63.00 & 74.00 \\
Postest & 10 & 37.000 & 2.35702 & 32.00 & 39.00 \\
\hline
\end{tabular}


Tabel 3 memperlihatkan penurunan rata-rata stres akademik kelompok siswa setelah diberikan perlakuan menggunakan teknik restrukturisasi kognitif dari 66,900 menjadi 37,000. Agar lebih representatif akan dipaparkan penurunan rata-rata stres akademik kelompok siswa melalui Gambar 3.

Gambar 3 menunjukkan keefektifan teknik restrukturisasi kognitif dalam menurunkan stres akademik kelompok siswa kelas eksperimen MTsN Wonorejo Kencong Jember. Namun berdasarkan Gambar 3 tidak cukup bukti untuk menguatkan dugaan bahwa teknik restrukturisasi kognitif efektif untuk menurunkan stres akademik siswa, maka untuk lebih menguatkan dugaan tersebut, dapat melihat hasil analisis data pada Tabel 4.

Tabel 4 memperlihatkan bahwa dari 10 data, terdapat 10 data mempunyai nilai beda negatif (negative ranks), tidak ada (0) data bernilai beda positif (positive ranks), dan tidak ada juga (0) data yang bernilai sama (ties). Dalam uji wilcoxon, yang dipakai adalah jumlah beda-beda yang paling kecil, karena itu dalam kasus ini diambil bedabeda positif (positive ranks), karena positif ranks mempunyai 0 data, sehingga diperoleh hasil seperti yang ditampilkan pada Tabel 5.
Test statistics ${ }^{\mathrm{a}}$ di atas menunjukkan nilai $\mathrm{Z}$ sebesar -2,807 dan asymp. sig. (2-tailed) sebesar 0,005. Artinya teknik restrukrurisasi kognitif efektif untuk menurunkan stres akademik kelompok siswa (kelompok eksperimen) di MTsN Wonorejo Kencong Jember.

\section{Keefektifan Problem Based Coping untuk Menurunkan Stres Akademik Siswa}

Untuk mengetahui sejauhmana keefektifan problem based coping untuk menurunkan stres akademik kelompok kontrol dapat dilihat dalam Tabel 6.

Tabel 6 menjelaskan penurunan rata-rata stres akademik kelompok siswa setelah diberikan perlakuan menggunakan problem based coping, yakni dari 61,100 menjadi 43,800. Untuk lebih representatif, Gambar 4 mengillustrasikan penurunan rata-rata stres akademik kelompok siswa setelah diberikan perlakuan menggunakan problem based coping.

Gambar 4 di atas dapat membantu memperjelas sejauhmana keefektifan problem based coping untuk menurunkan stres akademik siswa. Selanjutnya untuk lebih menguatkan

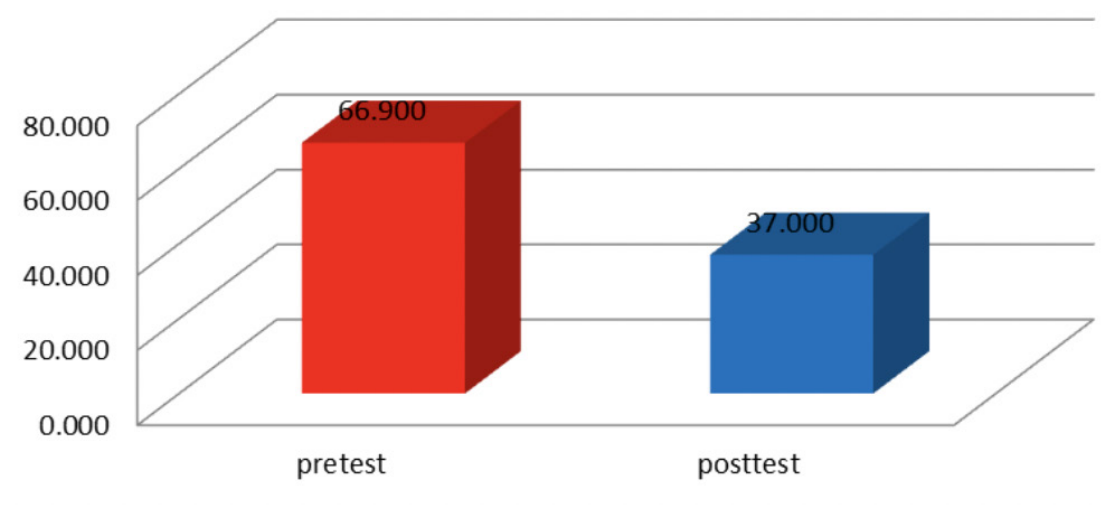

Gambar 3 Penurunan Rata-rata Stres Akademik Kelompok Eksperimen

Tabel 4 Wilcoxon Signed Ranks Test Kelompok Eksperimen

\begin{tabular}{llccc}
\hline \multicolumn{4}{c}{ Ranks } & \\
\hline & & N & Mean Rank & Sum of Ranks \\
\hline Postest - Pretest & Negative Ranks & $10^{\mathrm{a}}$ & 5.50 & 55.00 \\
& Positive Ranks & $0^{\mathrm{b}}$ & .00 & .00 \\
& Ties & $0^{\mathrm{c}}$ & & \\
& Total & 10 & & \\
\hline
\end{tabular}
a. Postest $<$ Pretest
b. Postest $>$ Pretest
c. Postest $=$ Pretest 
Table 5 Test Statistics $^{\mathrm{b}}$ Kelompok Eksperimen

\begin{tabular}{lc}
\hline \multicolumn{2}{c}{ Test Statistics $^{\mathrm{b}}$} \\
\hline & Postest - Pretest $^{\text {Pot }}$ \\
\hline $\mathrm{Z}$ & $-2.807^{\mathrm{a}}$ \\
Asymp. Sig. (2-tailed) & .005 \\
\hline
\end{tabular}

a. Based on positive ranks.

b. Wilcoxon Signed Ranks Test

Tabel 6 Descriptive Statistics Kelompok Kontrol

\begin{tabular}{llcccc}
\hline & N & Mean & Std. Deviation & Minimum & Maximum \\
\hline Pretest & 10 & 61.100 & 2.28279 & 58.00 & 63.00 \\
Posttest & 10 & 43.800 & 7.09930 & 39.00 & 63.00 \\
\hline
\end{tabular}

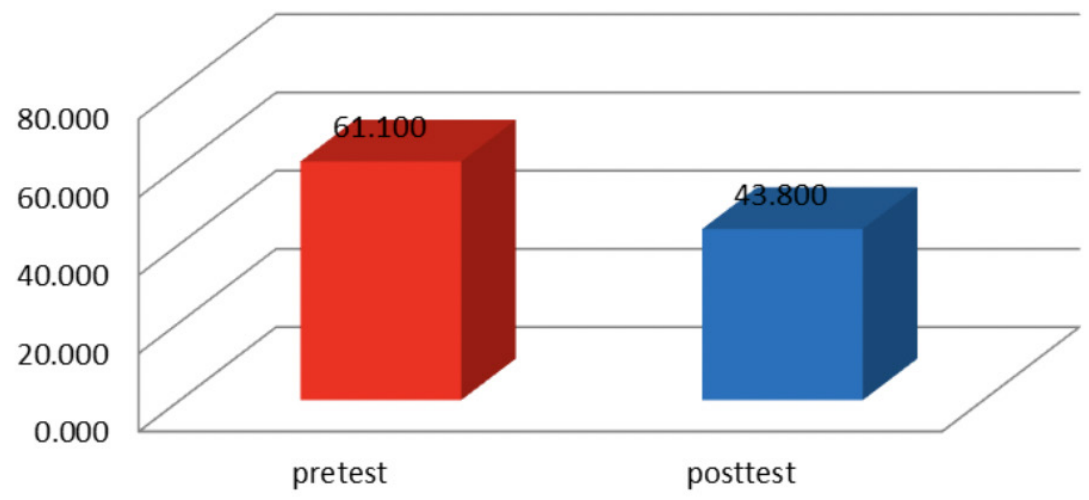

Gambar 4 Nilai Penurunan Rata-rata Stres Akademik Kelompok Kontrol

dugaan bahwa problem based coping efektif untuk menurunkan stres akademik kelompok siswa (kelompok kontrol) dapat dilihat hasil analisis Tabel 7.

Berdasarkan Tabel 7 terlihat bahwa dari 10 data, ada 9 data mempunyai nilai beda negatif (negative ranks), 0 data bernilai beda positif (positive ranks), dan 1 data yang bernilai sama (ties). Dalam uji wilcoxon, yang dipakai adalah jumlah beda-beda yang paling kecil, karena itu dalam kasus ini diambil beda-beda positif, karena positive ranks mempunyai 0 data. Selanjutnya pada Tabel 8 diperoleh nilai $\mathrm{Z}$ sebesar -2,677 dan asymp. sig. (2-tailed) sebesar 0,007. Artinya problem based coping efektif untuk menurunkan stres akademik kelompok siswa (kelompok kontrol) di MTsN Wonorejo Kencong Jember.

\section{Mann-Whitney}

Dalam penelitian ini Mann-Whitney digunakan untuk mencari apakah ada perbedaan teknik restrukturisasi kognitif dan problem based coping dalam menurunkan stres akademik siswa. Hasil analisis yang dilakukan dapat dilihat dalam
Tabel 9. Selanjutnya Tabel 10 memperlihatkan bahwa nilai $Z$ sebesar $-3,427$ dan nilai pada kolom asymp. sig. (2-tailed) sebesar 0,001. Artinya ada perbedaan teknik restrukturisasi kognitif dan problem based coping untuk menurunkan stres akademik siswa.

\section{PEMBAHASAN}

\section{Penurunan Stres Akademik dengan Teknik Restrukturisasi Kognitif}

Stres akademik kelompok siswa setelah diberikan perlakuan menggunakan teknik restrukturisasi kognitif didapati mengalami penurunan dari nilai rata-rata 66,900 menjadi 37,000 . Besarnya penurunan nilai rata-rata stres akademik ini tidak bisa menguatkan dugaan bahwa teknik restrukturisasi kognitif efektif untuk menurunkan stres akademik siswa. Sehingga dilakukan analisis Wilcoxon Signed Rank Test dengan hasil yang diperoleh dari 10 data, terdapat 10 data mempunyai nilai beda negatif (negative ranks) atau terdapat 10 orang siswa yang memiliki nilai stres akademik yang mengalami penurunan, 
Tabel 7 Wilcoxon Signed Ranks Test Kelompok Kontrol

\begin{tabular}{lllcc}
\hline \multicolumn{2}{c}{ Ranks } & & \\
\hline & & N & Mean Rank Sum of Ranks \\
\hline Posttest - Pretest & Negative Ranks & $9^{\mathrm{a}}$ & 5.00 & 45.00 \\
& Positive Ranks & $0^{\mathrm{b}}$ & .00 & .00 \\
& Ties & $1^{\mathrm{c}}$ & & \\
& Total & 10 & & \\
\hline
\end{tabular}
a. Posttest $<$ Pretest
b. Posttest $>$ Pretest
c. Posttest $=$ Pretest

Tabel 8 Test Statistics $^{\mathrm{b}}$ Kelompok Kontrol

\begin{tabular}{|c|c|c|c|c|}
\hline \multicolumn{4}{|c|}{ Test Statistics ${ }^{b}$} & \\
\hline \multicolumn{4}{|c|}{ Posttest - Pretest } & \\
\hline \multicolumn{2}{|c|}{$\begin{array}{l}\mathrm{Z} \\
\text { Asymp. Sig. (2-tailed) }\end{array}$} & \multicolumn{2}{|c|}{$-2.677^{a}$} & \\
\hline \multicolumn{5}{|c|}{$\begin{array}{l}\text { a. Based on positive ranks. } \\
\text { b. Wilcoxon Signed Ranks Test }\end{array}$} \\
\hline \multicolumn{5}{|l|}{ Tabel 9 Ranks } \\
\hline \multicolumn{5}{|c|}{ Ranks } \\
\hline Stres Akademik & $\begin{array}{l}\text { Kelas } \\
\text { restrukturisasi kognitif } \\
\text { problem based coping } \\
\text { Total }\end{array}$ & $\begin{array}{l}\mathbf{N} \\
10 \\
10 \\
20\end{array}$ & $\begin{array}{c}\text { Mean Rank } \\
6.10 \\
14.90\end{array}$ & $\begin{array}{c}\text { Sum of Ranks } \\
61.00 \\
149.00\end{array}$ \\
\hline
\end{tabular}

Tabel 10 Test Statistics ${ }^{\mathrm{a}}$ Mann-whitney

\begin{tabular}{lr}
\hline \multicolumn{2}{c}{ Test Statistics $^{\mathbf{b}}$} \\
\hline \multicolumn{2}{c}{ Stres Akademik } \\
\hline Mann-Whitney U & 6.000 \\
Wilcoxon W & 61.000 \\
Z & -3.427 \\
Asymp. Sig. (2-tailed) & .001 \\
Exact Sig. $[2 *(1-t a i l e d ~ S i g)]$. & $.000^{\mathrm{a}}$ \\
\hline a. Not corrected for ties. & \\
b. Grouping Variable: Kelas &
\end{tabular}

yakni: AH, FS, JM, KD, MA, MF, MR, MS, $\mathrm{NU}$, dan SA; selanjutnya 0 data bernilai beda positif (positive ranks) atau tidak ada siswa yang mempunyai nilai stres akademik yang mengalami kenaikan; dan tidak ada pula data yang bernilai sama (ties) atau nilainya sama pada (pretest dan posttest).

Selanjutnya dari test statistics ${ }^{a}$ diperoleh nilai Z sebesar-2,807 dan asymp. sig. (2-tailed) sebesar 0,005, yang artinya teknik restrukturisasi kognitif efektif untuk menurunkan stres akademik kelompok siswa (kelompok eksperimen) di MTsN Wonorejo Kencong Jember, dikarenakan 0,005 $<0,05$. Penurunan ini, menunjukkan bahwa teknik restrukturisasi kognitif telah berhasil memusatkan perhatiannya pada upaya mengidentifikasi dan mengubah kesalahan kognisi atau persepsi konseli tentang diri dan lingkungannya. Dalam mengatasi stres akademik siswa, teknik restrukturisasi kognitif menitikberatkan pada kognitif yang menyimpang akibat ketidaksiapan menghadapi tuntutan yang datang yang dapat merugikan dirinya baik secara fisik maupun psikis.

Hasil ini juga tampak menunjukkan bahwa teknik restrukturisasi kognitif dapat mengubah pandangan negatif siswa menjadi lebih realitistis. Tidak itu saja teknik restrukturisasi kognitif membantu siswa memahami distorsi kognitif (kesalahan berpikir) yang membuat siswa mengkritik diri dengan penilaian negatif (mengganggap dirinya tidak sebaik temannya). Dengan teknik restukturisasi kognitif, siswa tampak dapat memperbaiki pikiran yang irasional/tidak adaptif/negatif menjadi realistis, dan siswa mampu mengoreksi defisit perilaku adaptif dengan cara melatih keterampilan yang sebelumnya dimiliki (Yahav \& Cohen, 2008; Gunawan \& Palupi, 2012).

Hasil penelitian ini menunjukkan bahwa teknik restrukturisasi sudah sesuai dengan masalah 
situasional siswa (stres akademik), dan tampak pula bagi siswa yang sudah mengetahui kesalahan yang ada dalam pikirannya yang menyebabkan stres akademik, siswa telah mampu melawan pikiran tersebut agar tidak muncul kembali. Hasil penelitian menunjukkan bahwa kunci utama dari teknik restrukturisasi kognitif adalah seseorang mencari bukti-bukti obyektif yang menantang pikiran negatif, lalu secara aktif melakukan serangan dan tantangan terhadap pikiran negatif yang diyakininya (Indraswari, 2012). Seseorang diajarkan untuk menyerang dan menantang pikiran-pikirannya yang negatif, supaya kemudian dapat diganti dengan pikiran yang positif. Oleh karena itu, saat pikiran negatif muncul, individu perlu diajak untuk mencari alternatif pikiran.

\section{Penurunan Stres Akademik dengan Problem Based Coping}

Hasil analisis terhadap kelompok kontrol diperoleh nilai rata-rata stres akademik menurun dari 61,100 menjadi 43,800 setelah diberikan perlakuan menggunakan problem based coping. Penurunan ini dikuatkan dengan analisis Wilcoxon Signed Rank Test dengan hasil yang diperoleh dari 10 data, terdapat 9 data mempunyai nilai beda negatif (negative ranks) atau terdapat 9 orang siswa yang nilai stres akademiknya mengalami penurunan, yakni: BZ, DW, DP, KF, MAU, MJ, MAS, PS, dan WI; selanjutnya 0 data bernilai beda positif (positive ranks) atau tidak ada siswa yang memiliki nilai stres akademik yang mengalami penaikan; dan terdapat 1 data yang bernilai sama (ties) atau terdapat 1 orang siswa yang memiliki nilai pretest dan posttest sama, yakni: SN.

Selanjutnya analisis test statistics ${ }^{a}$ diperoleh nilai $\mathrm{Z}$ sebesar -2,677 dan asymp. sig. (2-tailed) sebesar 0,007 , yang artinya problem based coping efektif untuk menurunkan stres akademik kelompok siswa (kelompok kontrol) di MTsN Wonorejo Kencong Jember, karena 0,007 $<0,05$. Hasil analisis ini memperlihatkan bahwa siswa ( 9 orang) yang berada dalam kelompok kontrol (perlakuan dengan coping) telah mampu mereduksi tuntutan yang membebani, dan menimbulkan perubahan emosi pada dirinya, dikarenakan siswa telah berupaya meminta saran dan alternatif pemecahan masalah yang sedang dihadapinya. Sehingga dalam pereduksian ini siswa tampak berhasil mengurangi ketegangannya dengan memodifikasi atau meminimalisir keadaan yang dihadapinya, dan mengurangi ketidaknyamanannya dengan penilaian positif, penyangkalan, dan berpikir penuh harapan. Sementara itu 1 orang siswa lainnya tampak belum mampu mengubah masalah yang dihadapinya, maupun mengubah kondisi lingkungannya, dan siswa tampak sulit mencari dukungan sosial ataupun dukungan emosionalnya. Akibatnya siswa tampak kesulitan untuk menghadapi dan menyelesaikan masalahnya. Akhirnya siswa disarankan untuk berkonsultasi dengan guru/konselor atau mendatangi pusat bimbingan belajar atau program latihan lainnya yang dapat membantu siswa belajar lebih efektif. Dengan melakukan hal tersebut siswa telah menghadapi masalah yang dialami dan berusaha melakukan sesuatu untuk memecahkannya.

Penggunaan problem based coping dari hasil ini telah memperlihatkan bahwa individu merasa yakin bahwa dirinya dapat mengubah situasi atau dalam menghadapi tuntutan yang masih dapat dikontrol, dan mampu mengambil tindakan yang tepat untuk menyelesaikan masalahnya secara langsung. Hal ini terungkap berdasarkan hasil wawancara yang dilakukan peneliti terhadap salah satu siswa yang berinisial BZ, subjek mengungkapkan bahwa apabila dalam mengerjakan PR mengalami kesulitan, siswa sering berkonsultasi dengan teman-temannya yang sama-sama mengerjakan PR juga, bahkan terkadang bertanya kepada kakak kelasnya, mencari informasi tentang apa yang harus dilakukan dalam menghadapi kesulitan dan berusaha untuk mengetahui hal-hal baru yang berkaitan dengan pekerjaan rumahnya (Yahav \& Cohen, 2008; Hardika, et al., 2018).

Proses menghadapi masalah dan pemecahannya, kadangkala memiliki perbedaan tekanan yang berbeda bagi individu. Hal ini sesuai dengan pendapat yang menyatakan terkadang terdapat individu yang cenderung memiliki kepekaan dari adanya perbedaan tekanan dari persoalan yang sama, sehingga respons yang diberikan individu terhadap sebuah persoalan cenderung variatif, serta dinamis dan terdapat pula individu yang cenderung monoton dan tidak terbuka dalam melihat peluang-peluang penyelesaian persoalan (Carver, Scheier, \& Weintraub, 1989).

Tidak itu saja, dalam memandang sebuah masalah atau kesulitan dalam hidup dibutuhkan keoptimisan dan pantang menyerah untuk 
mencapai tujuan hidup dari individu itu sendiri. Ini sesuai dengan pendapat ahli yang mengatakan bahwa individu-individu yang optimis lebih sering mengatasi stres dengan aktif dan terorientasi pada tindakan serta menekankan penilaian positif terhadap peristiwa-peristiwa yang menimbulkan stres, sebaliknya individu-individu yang pesimis akan mengatasi stres secara pasif (Carver \& Scheier, 1989). Dengan begitu dibutuhkan usaha perilaku dan kognitif untuk menguasai, mengurangi atau bertahan terhadap tuntutan internal dan atau eksternal yang ditimbulkan oleh situasi yang penuh stres.

Usaha mengelola tuntutan ini dilakukan tanpa menghiraukan sukses atau tidaknya hasil dari usaha yang dilakukan, karena coping sendiri didefinisikan sebagai suatu proses dimana individu mencoba mengelola ketidaksesuaian antara tuntutantuntutan, baik tuntutan dari dalam diri individu maupun dari lingkungan dengan kemampuan yang digunakannya dalam menghadapi situasi stressful (Lazarus \& Folkman, 1984). Sementara pendapat lain menunjukkan bahwa proses coping bukanlah peristiwa tunggal, karena proses ini melibatkan transaksi dengan lingkungan (Sarafino; 2006). Individu dapat melakukan coping melalui transaksi antara perilaku dan kognitif dengan lingkungan, sehingga coping dapat dicapai bergantung pada asal munculnya distress, yang dapat timbul dari diri sendiri atau yang berasal dari lingkungan. Ketika stressor dipandang sebagai sebuah tantangan, maka coping yang dilakukan bersifat cenderung lebih adaptif dan konstruktif. Begitu pula sebaliknya, bila stressor dipandang individu sebagai sebuah ancaman, maka coping yang akan dipakai adalah jenis coping yang bersifat tidak konstruktif dan menghindar.

\section{Perbedaan Keefektifan Teknik Restrukturisasi Kognitif dan Problem Based Coping untuk menurunkan Stress Akademik Siswa}

Analisis Wilcoxon Signed Rank Test yang diperoleh dari masing-masing variabel bebas (teknik restrukturisasi kognitif dan problem based coping) sama-sama efektif untuk penurunan stres akademik siswa. Namun untuk melihat perbedaan masing-masing secara signifikan harus melalui analisis Mann-Whitney, analisis Mann-
Whitney diperoleh nilai $\mathrm{Z}$ sebesar -3,427 dan nilai asymp. sig. (2-tailed) sebesar 0,001, yang artinya probabilitas di bawah 0,05 . Maka kedua populasi berbeda dalam hal penurunan stres akademik atau dengan kata lain, data stres akademik kelompok siswa yang diberi perlakuan menggunakan teknik restrukturisasi kognitif berbeda secara signifikan dengan stres akademik kelompok siswa yang diberi perlakuan menggunakan problem based coping.

Hal yang terlihat dari analisis Wilcoxon Signed Rank Test, siswa yang diajarkan dengan teknik restrukturisasi kognitif didapat 10 data mempunyai nilai beda negatif (negative ranks), 0 data bernilai beda positif (positive ranks), dan 0 data juga yang bernilai sama (ties). Sementara siswa yang diajarkan dengan problem based coping diperoleh 9 data mempunyai nilai beda negatif (negative ranks), 0 data bernilai beda positif (positive ranks), dan 1 data yang bernilai sama (ties).

Perbedaan ini menguatkan fungsi teknik restrukturisasi kognitif dalam membantu konseli yang mengalami distres, distorsi kognitif, dan memperlihatkan resistensi terhadap metode perubahan perilaku, perbaikan konseptualisasi dan kepercayaan yang tidak fungsional (Yahav \& Cohen, 2008). Teknik restrukturisasi kognitif dalam penelitian ini telah mampu membantu konseli mengubah pola pikir negatif terhadap materi-materi pelajaran menjadi positif, sehingga berdampak pada berkurangnya tingkat stres akademik yang dialaminya. Hal ini terlihat dari kemampuan konseli mengetahui dan memahami akan terdapatnya kondisi kognitif yang "salah suai" dalam mempersepsi situasi-situasi akademik yang dihadapi, konseli juga mampu merasakan dan mengetahui dampak negatif dari memiliki pikiran-pikiran negatif terhadap situasi-situasi akademik yang dihadapi, selanjuntnya konseli mampu mengidentifikasi situasi-situasi akademik yang dipersepsi melebihi batas kemampuan dan mengancam, konseli mampu mengidentifikasi pikiran-pikiran negatif yang dimiliki terkait situasisituasi akademik, konseli mampu merumuskan pikiran-pikiran baru yang lebih positif sebagai pengganti pikiran-pikiran yang negatif sebelumnya, dan mampu merumuskan rencana tindakan yang berguna untuk memodifikasi pikiran negatif menjadi pikiran-pikiran positif. 


\section{KESIMPULAN}

Hasil analisis dengan Mann-Whitney dapat disimpulkan bahwa kedua populasi berbeda dalam hal penurunan stres akademik atau dengan kata lain, ada perbedaan teknik restrukturisasi kognitif dan problem based coping dalam menurunkan stres akademik siswa di MTsN Wonorejo Kencong Jember. Berdasarkan hasil penelitian, saran yang diajukan kepada pihak madrasah/sekolah adalah membantu konseli yang mengalami distres, distorsi kognitif, dan penilaian negatif menggunakan teknik restrukturisasi kognitif.

\section{DAFTAR RUJUKAN}

ABKIN. (2007). Penataan Pendidikan Profesional Konselor dan Layanan Bimbingan dan Konseling dalam Jalur Pendidikan Formal. Jakarta: Departemen Pendidikan Nasional.

Carver, S. C., \& Scheier, M. F. (1989). Assessing Coping Strategies: A Theoriticcelly Based Approach. Journal of Personality and Social Psychology, 56(2), 267-283.

Desmita, 2010. Psikologi Perkembangan. Bandung: PT Remaja Rosdakarya.

Dobson, D., \& Dobson, K. S. (2009). EvidanceBased Practice of Cognitive Behavioral Therapy. New York: The Guilford Press.

Gunawan, I. (2013). Statistika untuk Kependidikan Sekolah Dasar. Yogyakarta: Penerbit Ombak Yogyakarta.

Gunawan, I. (2016). Metode Penelitian Kuantitatif. (http://fip.um.ac.id/wp-content/ uploads/2015/12/2_Metpen-Kuantitatif.pdf). Retrieved 2 June 2018.

Gunawan, I., \& Palupi, A. R. (2012). Taksonomi Bloom - Revisi Ranah Kognitif: Kerangka Landasan untuk Pembelajaran, Pengajaran, dan Penilaian. Premiere Educandum Jurnal Pendidikan Dasar dan Pembelajaran, 2(2), 98-117.

Gunawan, I., Suraya, S. N., \& Tryanasari, D. (2014). Hubungan Kemampuan Berpikir Kreatif dan Kritis dengan Prestasi Belajar Mahasiswa pada Matakuliah Konsep Sains II Prodi PGSD IKIP PGRI MADIUN. Premiere Educandum Jurnal Pendidikan Dasar dan Pembelajaran, 4(1), 1-32.
Gusniarti, U. (2002). Hubungan antara Persepsi Siswa terhadap Tuntutan dan Harapan Sekolah dengan Derajat Stress Siswa Sekolah Plus. Psikologia: Jurnal pemikiran dan Penelitian Psikologi, 13(7), 53-68.

Hadi, S., Gunawan, I., \& Dalle, J. (2018). Statistika Inferensial: Teori dan Aplikasinya. Jakarta: Rajawali Pers.

Hardika, Aisyah, E. N., \& Gunawan, I. (2018). Facilitative Learning to Improve Student Learning Creativity. Paper presented at 3rd International Conference on Education Management and Administration (CoEMA 2018), Theme: The Challenges of Educational and Technology in Global and Local Era, Faculty of Education, Universitas Negeri Malang, Malang, 6-7 October 2018 (pp. 186189).

Hidayah, N., Hardika, Hotifah, Y., Susilawati, S. Y., \& Gunawan, I. (2017). Psikologi Pendidikan. Malang: Universitas Negeri Malang, Penerbit UM Press.

Indraswari, P. (2012). Modifikasi Kognitif Perilaku untuk Meningkatkan Self Remaja (dengan Teknik Restrukturisasi Kognitif, Visualisasi, dan Memperbaiki Penampilan Diri). (Unpublished master's thesis) Fakultas Psikologi Universitas Indonesia, Indonesia.

Lazarus, R. S., \& Folkman, S. (1984). Stress, Appraisal, and Coping. New York: Springer Publishing Company.

Papalia, D. E., Olds, S. W., \& Feldman, R. D. (2001). Human Development. New York: McGraw Hill.

Sarafino, E. P. (2006). Health Psychology Biopsychological Interactions. New York: John Wiley \& Sons Inc.

Sultoni, Gunawan, I., \& Sari, D. N. (2018). The Internalization of Character Values to Students: A Descriptive Study. Paper presented at International Conference on Education and Technology (ICET 2018), Faculty of Education, Universitas Negeri Malang, Malang, 26-27 October 2018 (pp. 169-171).

Suraya, S. N., Hartini, \& Gunawan, I. (2012). Persepsi Mahasiswa terhadap Kualitas Pelayanan Pendidikan FIP IKIP PGRI MADIUN. Jurnal Pendidikan, 18(1), 37-66. 
Taufik, \& Ifdil. (2013). Kondisi Stres Akademik Siswa SMA Negeri di Kota Padang. Jurnal Konseling dan Pendidikan, 1(2), 143-150.

Yahav, R., \& Cohen, M. 2008. Evaluation of Cognitive Behavior Interventation for Adolescents. International Journal of Stress Management, 15(2), 173-188. 